\title{
PEMAHAMAN SISTEM AKUNTANSI PEMERINTAH UNTUK MENINGKATKAN PERTANGGUNGJAWABAN KEUANGAN INSTANSI
}

\author{
Ratna Anggraini \\ Universitas Negeri Jakarta, ratna@feunj.ac.id \\ Nuramalia Hasanah \\ Universitas Negeri Jakarta, nuramalia@feunj.ac.id \\ Susi Indriani \\ Universitas Negeri Jakarta, susiindriani@feunj.ac.id \\ M. Yasser Arafat \\ Universitas Negeri Jakarta, yasser@feunj.ac.id \\ Marsellisa Nindito \\ Universitas Negeri Jakarta, marsellisa@feunj.ac.id
}

\begin{abstract}
The public demand for public transparency causes government accounting to be important. The greater the funds managed by the government the greater the demand for financial accountability as a form of financial transparency in government. The purpose of community service is firstly to understand the understanding of UNJ's financial department employees for the government accounting system, secondly to ensure the socialization of regulatory changes in the financial accountability of the institution is well understood by the finance staff, the third is to find solutions to the limited human resources that understand Accounting system of the financial section in the process of preparing financial statements.Participants attendes this training as many as 26 people, namely the representatives of the Central Finance Staff and Faculty of the State University of Jakarta, the results of the implementation of an understanding of the new government regulations on the preparation of financial statements and increasing the skills of participants in government financial accountability.
\end{abstract}

Kewords: Government Accounting System, Institutional Accountability 


\section{PENDAHULUAN}

\section{Analisis Situasi}

Perubahan paradigma dalam bidang kepemerintahan dalam era pasca reformasi menjadi topik utama dalam paradigma baru kepemerintahan di Indonesia. Aparatur pemerintah merupakan unsur pelayanan masyarakat perlu lebih dahulu menghayati serta menerapkannya sesuai tuntutan zaman yang sudah berubah. Bahwa paradigma lama yang selama ini menjadi aspek pemerintahan dengan kecenderungan dengan kekuasaan dan sekarang berubah menjadi kewenangan untuk pelayanan masyarakat, pemberdayaan masyarakat.

Sejalan dengan perubahan era reformasi tersebut baik secara internal maupun perubahan lingkungan strategik yang sudah merupakan keharusan setiap pegawai negeri (aparatur) memahami dan melaksanakan secara baik. Semenjak dimulai reformasi pada tahun 1998 lalu, telah membawa banyak perubahan dalam kehidupan berbangsa dan bernegara yang mempunyai implikasi mendalam dalam penyelenggaraan pemerintahan dan pembangunan di Indonesia. Melalui demokratisasi dan desentralisasi, keterbukaan, transparansi, akuntabilitas, penyelenggaraan pemerintahan di daerah sebagai ciri dari Good Governance atau kepemerintahan yang baik tersebut.

Dalam era globalisasi serta tuntutan reformasi yang semakin meningkat, peran akuntansi sebagai alat pencatatan semakin dibutuhkan.
Kepentingan itu tidak hanya diperuntukkan untuk pihak manajemen suatu entitas, tetapi juga untuk kebutuhan pertanggungjawaban (accountability) kepada banyak pihak yang memerlukan, Di dalam dunia bisnis (Commercial), akuntansi telah berkembang seiring dengan perkembangan bisnis tersebut. Hal ini menyebabkan akuntansi harus bisa menyesuaiakan dan berkembang seiring dengan perkembangan dunia bisnis.

Perkembangan akuntansi pemerintahan tidaklah secepat akuntansi bisnis. Penyebabnya adalah karakteristiknya tidak banyak mengalami perubahan. Dengan adanya tuntutan masyarakat menyebabkan akuntansi pemerintahan menjadi penting. Semakin besarnya dana yang dikelola oleh pemerintah semakin besar pula tuntutan akuntabilitas keuangan sebagai wujud transparansi keuangan dalam pemerintahan.

\section{Perumusan Masalah}

Berdasarkan uraian di atas, dapat diidentifikasi berbagai masalah sebagai berikut:

1. Apakah staf bagian keuangan sudah mendapatkan pemahaman mengenai sistem akuntansi pemerintah?

2. Apakah sosialisasi perubahan peraturan dalam pertanggungjawaban keuangan instansi sudah dipahami dengan baik oleh staf bagian keuangan?

3. Apakah keterbatasan sdm yang memahami sistem akuntansi dari bagian keuangan dapat meng- 
hambat dalam proses penyusunan laporan keuangan yang baik?

Berdasarkan identifikasi masalah di atas, maka perumusan masalah dalam program pengabdian masyarakat ini adalah Sosialisasi Pemahaman Sistem Akuntansi Untuk Meningkatkan Pertanggungjawaban Keuangan Instansi.

Peserta yang akan hadir ada pelatihan ini direncanakan sebanyak 30 - 40 orang yaitu perwakilan Staf Bagian Keuangan Pusat dan FakultasFakultas dari Universitas Negeri Jakarta.

\section{Tujuan}

Pelatihan ini bertujuan untuk:

1. Meningkatkan kemampuan staf bagian keuangan agar mampu memahami sistem akuntansi pemerintah.

2. Meningkatkan kemampuan staf bagian keuangan agar mampu memahami perubahan peraturan dalam pertanggungjawaban keuangan isnstansi.

3. Meningkatkan kemampuan pengelola dana PPMK agar mampu melakukan pencatatan dan pelaporan keuangan atas dana yang dikelolanya.

4. Meningkatkan kemampuan staf bagian keuangan agar mampu menyusun laporan keuangan instansi yang sesuai dengan peraturan pemerintah yang berlaku.

\section{Manfaat Kegiatan}

Manfaat yang diperoleh atas pelatihan ini adala : a. Peserta Pelatihan :

1. Peserta memahami informasi yang akurat dan tepat waktu tentang anggaran dan kegiatan keuangan pemerintah pusat.

2. Peserta memahami informasi uang dapat dipercaya tentang posisi keuangan suatu instansi dan pemerintah pusat secara keseluruhan.

3. Peserta memahami pencatatan dan pelaporan keuangan yang berguna untuk perencanaan, pengelolaan dan pengendalian kegiatan keuangan pemerintah secara efisien.

b. Tim Pengabdian Masyarakat :

1. Memberikan kontribusi pengetahuan kepada masyarakat dalam rangka memberdayakan masyarakat dan memcerdaskan bangsa sesuai dengan pengetahun pengalaman yang dimiliki oleh instruktur.

2. Memahami aspek praktek dalam penyusunan laporan keuangan secara efisien.

3. Membantu Pemerintah dalam rangka sosialisasi peraturan agar semakin banyak staf keuangan yang memahami sistem akuntansi pemerintah

\section{KAJIAN TEORITIK}

Dasar Hukum Penyelenggaraan Sistem Akuntansi Pemerintah Pusat

Undang-undang Nomor 17 Tahun 2003 tentang Keuangan Negara Pasal 8 menyatakan bahwa "dalam rangka pelaksanaan kekuasaan atas pengelolaan fiskal, Menteri Keuangan 
mempunyai tugas antara lain menyusun laporan keuangan yang merupakan pertanggungjawaban pelaksanaan APBN."

Undang-undang Nomor 17 Tahun 2003 tentang Keuangan Negara Pasal 9 menyatakan bahwa "Menteri/ Pimpinan Lembaga sebagai pengguna anggaran/pengguna barang Kementerian Negara/Lembaga yang dipimpinnya mempunyai tugas antara lain menyusun dan menyampaikan laporan keuangan Kementerian Negara/ Lembaga yang dipimpinnya."

Undang-undang Nomor 17 Tahun 2003 tentang Keuangan Negara Pasal 30 ayat (2) menyatakan bahwa "Presiden menyampaikan rancangan undang-undang tentang pertanggungjawaban pelaksanaan APBN kepada DPR berupa laporan keuangan yang meliputi Laporan Realisasi APBN, Neraca, Laporan Arus Kas, dan Catatan atas Laporan Keuangan, yang dilampiri dengan laporan keuangan perusahaan negara dan badan lainnya."

Undang-undang Nomor 1 Tahun 2004 tentang Perbendaharaan Negara Pasal 7 ayat (20) menyatakan bahwa "Menteri Keuangan selaku Bendahara Umum Negara berwenang menetapkan sistem akuntansi dan pelaporan keuangan Negara."

Undang-undang Nomor 1

Tahun 2004 tentang Perbendaharaan Negara Pasal 51 ayat (1) menyatakan bahwa "Menteri Keuangan/Pejabat Pengelola Keuangan Daerah selaku Bendahara Umum Negara/Daerah menyelenggarakan akuntansi atas transaksi keuangan, aset, utang, dan ekuitas dana, termasuk transaksi pembiayaan dan perhitungannya."

Undang-undang Nomor 1 Tahun 2004 tentang Perbendaharaan Negara Pasal 51 ayat (2) menyatakan bahwa "Menteri/pimpinan lembaga/ kepala satuan kerja perangkat daerah selaku Pengguna Anggaran menyelenggarakan akuntansi atas transaksi keuangan, aset, utang, dan ekuitas dana, termasuk transaksi pendapatan dan belanja yang berada dalam tanggung jawabnya."

\section{Undang-undang Nomor 1} Tahun 2004 tentang Perbendaharaan Negara Pasal 55 ayat (1) menyatakan bahwa "Menteri Keuangan selaku pengelola fiskal menyusun Laporan Keuangan Pemerintah Pusat untuk disampaikan kepada Presiden dalam rangka memenuhi pertanggungjawaban pelaksanaan APBN."

\section{Undang-undang Nomor 1}

Tahun 2004 tentang Perbendaharaan Negara Pasal 55 ayat (2) menyatakan bahwa "dalam menyusun Laporan Keuangan Pemerintah Pusat sebagaimana dimaksud pada ayat (1), menteri/pimpinan lembaga selaku Pengguna Anggaran/Pengguna Barang menyusun dan menyampaikan laporan keuangan yang meliputi Laporan Realisasi Anggaran, Neraca, dan Catatan atas Laporan Keuangan dilampiri laporan keuangan Badan Layanan Umum pada kementerian negara/Lembaga masing-masing."

Penjelasan atas Undang-undang Republik Indonesia Nomor 1 Tahun 2004 tentang Perbendaharaan Negara, 
menyatakan bahwa "agar informasi yang disampaikan dalam laporan keuangan pemerintah dapat memenuhi prinsip transparansi dan akuntabilitas, perlu diselenggarakan Sistem Akuntansi Pemerintah Pusat (SAPP) yang terdiri dari Sistem Akuntansi Pusat (SiAP) yang dilaksanakan oleh Kementerian Keuangan dan Sistem Akuntansi Instansi (SAI) yang dilaksanakan oleh kementerian negara/lembaga."

Undang-undang Nomor 36 Tahun 2004 tentang Anggaran Pendapatan dan Belanja Tahun Anggaran 2005 Pasal 17 ayat (1) menyatakan bahwa "setelah Tahun Anggaran 2005 berakhir, Pemerintah menyusun Pertanggungjawaban atas Pelaksanaan Anggaran Pendapatan dan Belanja Negara Tahun Anggaran 2005 berupa Laporan Keuangan."

Keputusan Presiden Nomor 42 Tahun 2002 tentang Pedoman Pelaksanaan Anggaran Pendapatan dan Belanja Negara pada Pasal 60 ayat (1) menyatakan bahwa "Menteri/ Pimpinan Lembaga wajib menyelenggarakan pertanggungjawaban penggunaan dana bagian anggaran yang dikuasainya berupa laporan realisasi anggaran dan neraca Kementerian Negara/Lembaga bersangkutan kepada Presiden melalui Menteri Keuangan. Keputusan Presiden tersebut telah diubah dengan Keputusan Presiden No. 72 tahun 2004 tentang Pedoman Pelaksanaan Anggaran Pendapatan dan Belanja Negara."

\section{Ruang Lingkup SAPP}

Sistem Akuntansi Pemerintah Pusat (SAAP) berlaku untuk seluruh unit organisasi Pemerintah Pusat dan unit akuntansi pada Pemerintah Daerah dalam rangka pelaksanaan Dekonsentrasi dan/atau Tugas Pembantuan serta pelaksanaan Anggaran Pembiayaan dan Perhitungan.

Menurut UU keuangan negara, yang tidak termasuk dalam ruang lingkup SAPP adalah :

a. Pemerintah Daerah (sumber dananya berasal dari APBD)

b. Badan Usaha Milik Negara/Badan Usaha Milik Daerah yang terdiri dari :

c. Perusahaan Perseroan, dan

d. Perusahaan Umum.

e. Bank Pemerintah dan Lembaga Keuangan Milik Pemerintah

Tujuan dari SAPP manurut Noordiawan (2009) adalah:

1. Menjaga asset (safe guarding asset), agar asset pemerintah dapat terjaga melalui serangkaian proses pencatatan, pengolahan dan pelaporan keuangan yang konsisten sesuai dengan standar.

2. Memberikan informasi yang relevan, menyediakan informasi yang akurat dan tepat waktu tentang anggaran dan kegiatan keuangan pemerintah pusat.

3. Memberikan informasi yang dapat dipercaya tentang posisi keuangan suatu instansi dan pemerintah pusat secara keseluruhan.

4. Menyediakan informasi keuangan yang berguna untuk perencanaan, pengelolaan, dan pengendalian 
kegiatan dan keuangan pemerintah secara efisien.

\section{Kerangka Umum SAPP}

Berdasarkan PMK Nomor 171/PMK.05/2007 tentang Sistem Akuntansi dan Pelaporan Keuangan Pemerintah Pusat, SAPP memiliki 2 (dua) subsistem, yaitu Sistem Akuntansi Bendahara Umum Negara (SA-BUN) dan Sistem Akuntansi Instansi (SAI).

SA-BUN dilaksanakan oleh Kementerian Keuangan selaku Bendahara Umum Negara / Chief Financial Officer (CFO). Selanjutnya, SA-BUN memiliki beberapa subsistem, yaitu

1. Sistem Akuntansi Pusat (SiAP);

2. Sistem Akuntansi Utang Pemerintah dan Hibah (SAUP \& $\mathrm{H})$;

3. Sistem Akuntansi Transfer ke Daerah (SA-TD);

4. Sistem Akuntansi Penerusan Pinjaman (SA-PP);

5. Sistem Akuntansi Investasi Pemerintah (SA-IP);

6. Sistem Akuntansi Transaksi Khusus (SA-TK);

7. Sistem Akuntansi Subsidi dan Belanja Lainnya (SA-BSBL);

8. Sistem Akuntansi Badan lainnya (SA-BL).

SAI memiliki 2 (dua) subsistem, yaitu Sistem Akuntansi Keuangan (SAK) dan Sistem Informasi Manajemen dan Akuntansi Barang Milik Negara (SIMAK-BMN). SAI dilaksanakan oleh Menteri/Ketua Lembaga Teknis selaku Chief Operational Officer (COO).
SA-BUN adalah serangkaian prosedur manual maupun yang terkomputerisasi mulai dari pengumpulan data, pencatatan, pengikhtisaran sampai dengan pelaporan posisi keuangan dan operasi keuangan pada Kementerian Keuangan selaku Bendahara Umum Negara. Laporan Keuangan yang dihasilkan berupa Laporan Realisasi Anggaran termasuk pembiayaan, Neraca, Laporan Arus Kas serta dilengkapi dengan Catatan atas Laporan Keuangan.

Sistem Akuntansi Instansi (SAI) dilaksanakan oleh kementerian negara/lembaga. Kementerian negara/ lembaga melakukan pemrosesan data untuk menghasilkan Laporan Keuangan berupa Laporan Realisasi Anggaran, Neraca dan Catatan atas Laporan Keuangan.

SAK digunakan untuk memproses transaksi anggaran dan realisasinya, sehingga menghasilkan Laporan Realisasi Anggaran. Sedangkan SIMAK-BMN memproses transaksi perolehan, perubahan dan penghapusan BMN untuk mendukung SAK dalam rangka menghasilkan Laporan Neraca. Di samping itu, SIMAK-BMN menghasilkan berbagai laporan, buku-buku, serta kartu-kartu yang memberikan informasi manajerial dalam pengelolaan BMN.

Ciri-ciri pokok sistem akuntansi pemerintah pusat antara lain:

a. Basis Akuntansi

Cash toward Accrual. Basis akuntansi yang digunakan dalam laporan keuangan pemerintah adalah basis kas untuk pengakuan pendapatan, 
belanja, dan pembiayaan dalam Laporan Realisasi Anggaran dan basis akrual untuk pengakuan aset, kewajiban, dan ekuitas dalam neraca. Basis Kas adalah basis akuntansi yang mengakui pengaruh transaksi dan peristiwa lainnya pada saat kas atau setara kas diterima atau dibayar. Basis akrual adalah basis akuntansi yang mengakui pengaruh transaksi dan peristiwa lainnya pada saat transaksi atau peristiwa itu terjadi, tanpa memperhatiakan saat kas atau setara kas diterima atau dibayar.

b. Sistem Pembukuan Berpasangan.

Sistem Pembukuan Berpasangan didasarkan atas persamaan dasar akuntasi yaitu : Aset = Kewajiban + Ekuitas Dana. Setiap transaksi dibukukan dengan mendebet sebuah perkiraan dan mengkredit perkiraan yang terkait.

c. Dana Tunggal

Kegiatan akuntansi yang mengacu kepada UU-APBN sebagai landasan operasional. Dana tunggal ini merupakan tempat dimana Pendapatan dan Belanja Pemerintah dipertanggungjawabkan sebagai kesatuan tunggal

d. Desentralisasi Pelaksanaan Akuntansi

Kegiatan akuntansi dan pelaporan keuangan di instansi dilaksanakan secara berjenjang oleh unit-unit akuntansi baik di kantor pusat instansi maupun di daerah.

e. Bagan Perkiraan Standar SAPP menggunakan perkiraan standar yang ditetapkan oleh Menteri
Keuangan yang berlaku untuk tujuan penganggaran maupun akuntansi.

\section{Standar Akuntansi Pemerintah}

SAPP mengacu pada Standar Akuntansi Pemerintah (SAP) dalam melakukan pengakuan, penilaian, pencatatan, penyajian, dan pengungkapan terhadap transaksi keuangan dalam rangka penyusunan laporan keuangan.

SAPP terbagi menjadi 2 subsistem, yaitu:

1. Sistem akuntansi Pusat (SiAP) merupakan bagian SAPP yang dilaksanakan oleh Direktorat Informasi dan Akuntansi (DIA) yang akan menghasilkan laporan keuangan pemerintah pusat untuk pertanggungjawaban pelaksanaan APBN. SiAP sendiri terbagi menjadi 2 subsistem, yaitu Sistem Akuntansi Kas Umum Negara (SAKUN) dan Sistem Akuntansi Umum (SAU).

2. Sistem akuntansi Instansi (SAI) merupakan bagian SAPP yang akan menghasilkan laporan keuangan untuk pertanggungjawaban pelaksanaan anggaran instansi. SAI sendiri terbagi menjadi 2 subsistem, yaitu system Akuntansi keuangan (SAK) dan Sistem Akuntansi Barang Milik Negara (SABMN).

\section{Sistem Akuntansi Pusat}

SiAP merupakan serangkaian prosedur manual maupun terkomputerisasi, mulai dari pengumpulan data, 
pencatatan, pengikhtisaran, sampai pelaporan posisi dan operasi keuangan pada menteri keuangan selaku bendahara umum Negara(BUN). SiAP memproses data transaksi KUN dan Akuntansi umum.

SiAP terdiri atas :

1. SAKUN, yaitu subsistem SiAP yang menghasilkan laporan arus kas dan neraca KUN.

2. SAU, yaitu subsistem SiAPyang akan menghasilkan LRA pemerintah pusat.

\section{Sistem Akuntansi Instansi}

SAI adalah serangkaian prosedur manual terkomputerisasi mulai dari pengumpulan data, pencatatan, pengikhtisaran, sampai dengan pelaporan posisi keuangan dan operasi keuangan pada kementrian negara/lembaga.

SAI terdiri atas dua subsistem, yaitu:

1. SAK; subsistem dari SAI yang menghasilkan informasi mengenai LRA, neraca, dan catatan atas laporan keuangan milik kementrian/instansi

2. SABMN; subsistem dari SAI yang merupakan serangkaian prosedur yang saling berhubungan untuk mengolah dokumen sumber dalam rangka menghasilkan informasi untuk menyusun neraca dan laporan Barang Milik Negara serta laporan manajerial lainnya menurut ketentuan yang berlaku.

\section{Sistem Akuntansi Keuangan}

SAK seperti halnya SAU, menghasilkan LRA, Neraca, dan
Catatan atas Laporan keuangan, namun laporan keuangan yang dihasilkan tersebut merupakan laporan keuangan pada tingkat kementrian/lembaga.

Struktur organisasi kementrian /lembaga sangat berjenjang dimulai dari kementrian/lembaga sampai dengan kantor/satuan kerja, karena itu dalam pelaksanaannya, dibentuk unit akuntansi keuangan pada jenjangjenjang tersebut. Proses akuntansi diawali dari unit terendah, yaitu unit akuntansi pada level kantor. Laporan keuangan yang dihasilkan kemudian akan diberikan kepada unit akuntansi diatasnya untuk digabung. Demikian seterusnya, sehingga pada akhirnya akan diperoleh laporan keuangan pada tingkat kementrian / lembaga.

Unit akuntansi keuangan yang telah dijelaskan di bagian sebelumnya adalah:

a) Unit Akuntansi Pengguna Anggaran (UAPA), yang berada pada level Kementrian/ Lembaga

b) Unit Akuntansi Pembantu Pengguna Anggaran-Eselon 1 (UAPPAE1), yang berada pada level eselon 1.

c) Unit Akuntansi Pembantu Pengguna Anggaran-Wilayah (UAPPAW) yang berada pada tingkat wilayah.

d) Unit Akuntansi Kuasa Pengguna Anggaran (UAKPA) yang berada pada level Kuasa Pengguna Anggaran (Kantor). 


\section{Sistem Akuntansi Barang Milik Negara}

Secara umum, barang adalah bagian dari kekayaan yang merupakan satuan tertentu yang dapat dinilai/ dihitung/diukur/ditimbang, tidak termasuk uang dan surat berharga.

Menurut UU Nomor 1 Tahun 2004, Barang Milik Negara adalah semua barang yang dibeli atau diperoleh atas beban APBN atau berasal dari perolehan lainnya yang sah. Contoh perolehan lainnya yang sah adalah hibah atau rampasan/ sitaan.

Tidak termasuk dalam pengertian Barang Milik Negara adalah barang-barang yang dikuasai atau dimiliki oleh:

a. Pemda (bersumber dari APBD)

b. BUMN/ BUMD

c. Bank pemerintah dan lembaga keuangan milik pemerintah

Dalam akuntansi pemerintah pusat, SABMN sebagai subsistem dari Sistem Informasi Akuntansi bertujuan menghasilkan neraca dan laporan barang milik daerah.

Untuk mencapai tujuan tersebut, Kementrian/Lembaga membentuk Unit Akuntansi Barang sebagai berikut:

a) Unit Akuntansi Pengguna Barang (UAPB), berada pada level Kementrian/Lembaga. Penanggungjawabnya adalah menteri/ pimpinan lembaga.

b) Unit Akuntansi Pembantu Pengguna Barang-Eselon 1 (UAPPB-E1), yang berada pada level eselon 1.
Penanggungjawabnya adalahpejabat eselon 1.

c) Unit Akuntansi Pembantu Pengguna Barang-Wilayah (UAPPB-W) yang berada pada tingkat wilayah. Penanggungjawabnya adalah kepala kantor wilayah atau kepala unit kerja yang ditetapkan sebagai UAPPB-W.

d) Unit Akuntansi Kuasa Pengguna Barang (UAKPB) yang berada pada level Kuasa Pengguna Anggaran (kantor). Penanggungjawabnya adalh kepala kantor/satuan kerja.

Unit Akuntansi Barang, selain melakukan proses terhadap dokumen sumber untuk menghasilkan laporan barang milik negara, juga wajib berkoordinasi dengan Unit Akuntansi Keuangan untuk penyusunan nerac serta dalam pembuatan catatan atas laporan keuangan khususnya catatan mengenai barang milik negara.

\section{Pelaporan dan Pertanggungjawaban Dana Dekonsentrasi dan Tugas Perbantuan}

Dalam penyelenggaraan pemerintahan, pemerintah menggunakan asas:

1. Desentralisasi; penyerahan wewenang pemerintahan oleh Pemerintah kepada daerah otonom untuk mengatur dan mengurus urusan pemerintah dalam sistem Negara Kesatuan Republik Indonesia.

2. Dekosentrasi; pelimpahan wewenang pemerintahan oleh Pemerintah kepada Gubernur 
sebagai wakil pemerintah dan/ atau kepada instansi vertical di wilayah tertentu.

3. Tugas pembantuan; penugasan dari Pemerintah kepada daerah dan/atau desa dari pemerintah provinsi kepada kabupaten/kota dan/atau desa serta dari pemkab/pemkot kepada desa untuk melaksanakan tugas tertentu.

Dana yang terkait dengan desentralisasi merupakan dana yang bersumber dari APBN dan dalam pelaksanaannya ditransfer lansung ke Kas Umum Daerah. Dana ini berupa dana pertimbangan (dana alokasi umum, dana alokasi khusus, dan dana bagi hasil). Terhadap dana ini, pelaporan dan pertanggungjawaban dilakukan di masing-masing daerah.

Namun untuk dana dekonsentrasi dan dana tugas perbantuan, satuan kerja yang menerima melaporkan dan mempertanggungjawabkan penggunaan dana tersebut $\mathrm{K} / \mathrm{L}$ teknis yang terkait. Pertanggungjawaban dana dekonsentrasi dan tugas pembantuan ini akan digabung dengan laporan keuangan dan laporan barang milik Negara (yang telah dijelaskan SAI) sehingga menjadi laporan keuangan Kementerian/Lembaga dan laporan barang milik Negara kementerian/ lembaga.

\section{Laporan Keuangan Pemerintah Pusat}

Laporan Keuangan merupakan output yang dihasilkan dari suatu system akuntansi. Untuk pemerintah pusat, laporan keuangan yang dihasilkan merupakan laporan keuangan konsolidasi dari laporan keuangan dua subsistemnya, yaitu: Laporan keuangan yang dihasilkan SiAP dan SAI.

Laporan Keuangan Pemerintah Pusat disampaikan kepada DPR sebagai pertanggungjawaban atas pelaksanaan APBN. Sebelum disampaikan kepada DPR, laporan keuangan pemerintah pusat tersebut diaudit terlebih dahulu oleh pihak BPK.

Laporan Keuangan Pemerintah Pusat berdasar PP 71/2010 terdiri dari:

a. Laporan Realisasi Anggaran

Konsolidasi Laporan Realisasi Anggaran dari seluruh Kementerian Negara/Lembaga yang telah direkonsiliasi. Laporan ini menyajikan informasi realisasi pendapatan, belanja, transfer, surplus/ defisit dan pembiayaan, sisa lebih/kurang pembiayaan anggaran yang masing-masing diperbandingkan dengan anggaran dalam satu periode.

b. Laporan Saldo Anggaran Lebih Isi laporan ini,berupa mutasi Saldo Anggaran Lebih (SAL) yang merupakan akumulasi saldo SiLPA/ SiKPA dari LRA,adapun struktur laporan SAL adalah sebagai berikut:

1. Saldo Anggaran Lebih awal;

2. Penggunaan Saldo Anggaran Lebih;

3. Sisa Lebih/Kurang Pembiayaan Anggaran tahun berjalan; 
4. Koreksi Kesalahan Pembukuan tahun Sebelumnya; dan

5. Lain-lain

c. Neraca Pemerintah

Neraca Pemerintah Pusat merupakan konsolidasi Neraca SAI dan Neraca SAKUN (Sistem Akuntansi Kas Umum Negara). Laporan in menyajikan informasi posisi keuangan pemerintah pusat berkaitan dengan aset, utang dan ekuitas dana pada tanggal/tahun anggaran tertentu.

d. Laporan Operasional

Laporan ini seperti laporan yang laba rugi yang menentukan surplus atau defisit dari kegiatan operasional. Adapun struktur laporan adalah sebagai berikut:

1. Pendapatan-LO dari kegiatan operasional

2. Beban dari kegiatan operasional

3. Surplus/Defisit dari Kegiatan Non Operasional, bila ada

4. Pos luar biasa, bila ada

5. Surplus/defisit-LO

e. Laporan Arus Kas

Laporan Arus Kas Pemerintah Pusat merupakan konsolidasi Laporan Arus Kas dari seluruh Kanwil Ditjen PBN. Laporan ini menyajikan informasi arus masuk dan keluar kas selama periode tertentu yang diklasifikasikan berdasarkan aktivitas operasi, investasi aset non keuangan, pembiayaan dan non anggaran

f. Catatan Atas Laporan Keuangan Merupakan penjelasan atau perincian atau analisis atas nilai suatu pos yang tersaji di dalam
Laporan Realisasi Anggaran, Neraca Pemerintah dan Laporan Arus Kas dalam rangka pengungkapan yang memadai.

\section{METODOLOGI}

Kerangka Pemecahan Masalah

Kerangka atau tahapan dalam pelatihan Sosialisasi Pemahaman Sistem Akuntansi Pemerintah Untuk Meningkatkan Pertanggungjawaban Keuangan Instansi adalah sebagai berikut:

\section{Analisis Kebutuhan}

Berdasarkan diskusi yang dilakukan oleh tim pengabdian masyarakat pada program pelatihan ini, para staf bagian keuangan memerlukan program pelatihan ini dengan pertimbangan :

a) Kurangnya pemahaman staf bagian keuangan mengenai sistem akuntansi pemerintah.

b) Kurangnya pemahaman staf bagian keuangan terhadap perubahan peraturan dalam pertanggungjawaban keuangan instansi.

c) Kurangnya pemahaman staf bagian keuangan untuk meyusun laporan keuangan instansi yang sesuai dengan Standar Akuntansi Pemerintah.

\section{Rancangan Instruksional}

Dalam menentukan rancangan instruksional ini perlu dipertimbangkan aspek-aspek berikut :

a) Isi materi program pelatihan yang relevan dengan kebutuhan mereka. 
Tim ini telah memetakan kebutuhan materi keseluruhan bagi staf bagian keuangan yang dibagi dalam 2 materi pelatihan yang akan dijelaskan pada bagian materi pelatihan.

b) Latar belakang staf bagian keuangan misalnya pendidikan, pekerjaan utama, usia dan sebagainya.

c) Modul praktek yang digunakan pada pelatihan ini harus membantu peserta pelatihan memahami aspek teknis sistem akuntansi pemerintah dalam penyusunan laporan keuangan.

\section{Tahap Pengembangan}

Dalam rangka pengembangan program pelatihan sosialisasi pemahaman sistem akuntansi pemerintah, tim pengabdian masyarakat berupaya mengembangkan pelatihan ini baik dalam hal materi pelatihan, modul dan tanya jawab dalam bentuk yang relevan dengan aspek Pendokumentasian dan Penyusunan Laporan Keuangan Pemerintah secara efisien.

\section{Realisasi Pemecahan Masalah}

\section{Pelaksanaan}

Pelaksanaan program pelatihan ini direncanakan pada hari Kamis di bulan Juni tahun 2013 di ruang kelas di Gedung N. Waktu yang dialokasikan dalam pelatihan 3 aspek yang direncanakan yaitu 4 jam pelatihan atau kira-kira dimulai pada jam 08.30 - 14.00 WIB.
2. Evaluasi

Tim pengabdian masyarakat akan menyusun evaluasi terkait dengan pemahaman peserta terhadap materi pelatihan, pelaksanaan pelatihan secara keseluruhan untuk menampung kemungkinan dibutuhkannya pelatihan dengan materi lain dan tertibnya pelaksanaan program pelatihan ini.

3. Khalayak Sasaran

Peserta yang hadir sebanyak 30 40 orang yaitu perwakilan staf bagian keuangan Universitas Negeri Jakarta baik dari Pusat maupun dari setiap Fakultas. Setiap bagian keuangan diharapkan diwakili oleh 2 - 3

\section{Metode Yang Digunakan}

Metode pelatihan yang digunakan pada program pelatihan ini diharapkan dapat memberikan kemudahan kepada peserta pelatihan. Dalam pelatihan ini, metode yang digunakan adalah Metode Penjelasan, Praktek dan Tanya Jawab. Pada Metode Penjelasan, setiap instruktur menyampaikan materi terkait selama 30 menit kemudian dilanjutkan dengan sesi Praktek dan Tanya Jawab selama 30 menit. Instruktur direncanakan akan membuat power point slide dan modul ringkas praktek pelatihan yang akan dibagikan kepada peserta pelatihan sebelum program dimulai.

Alat bantu pelatihan seperti LCD proyektor juga digunakan agar peserta lebih mudah memahami 
materi pelatihan sementara instruktur lainnya juga mendampingi para peserta untuk memantau pertanyaanpertanyaan selama sesi praktek dan tanya jawab.

\section{Materi Pelatihan \& Instruktur}

Materi pelatihan yang akan disampaikan dan instruktur pada program pelatihan ini dijelaskan pada tabel dibawah ini.

Tabel 1

Materi Pelatihan \& Instruktur

\begin{tabular}{|c|c|c|c|}
\hline $\mathrm{NO}$ & MATERI & INSTRUKTUR & JUMLAH JAM \\
\hline 1 & $\begin{array}{l}\text { Konsep } \quad \text { Dasar } \\
\text { Akuntansi Pemerintah }\end{array}$ & Tim BPKP & 1 Jam \\
\hline 2 & $\begin{array}{l}\text { Sistem Akuntansi } \\
\text { Pemerintah }\end{array}$ & Tim BPKP & 1 Jam \\
\hline 3 & $\begin{array}{lr}\text { Tahapan } & \text { Penyusunan } \\
\text { Laporan } & \text { Keuangan } \\
\text { Pemerintah } & \\
\end{array}$ & Tim BPKP & 1 Jam \\
\hline 4 & $\begin{array}{lr}\text { Pemahaman } & \text { Laporan } \\
\text { Keuangan } & \text { (Studi } \\
\text { Kasus) } & \\
\end{array}$ & Tim BPKP & $1 \mathrm{Jam}$ \\
\hline & Total Alokasi Waktu & & $4 \mathrm{Jam}$ \\
\hline
\end{tabular}

\section{HASIL DAN PEMBAHASAN}

Kegiatan Pelatihan bertujuan untuk memberikan informasi tentang pemahaman system informasi akuntansi dalam rangka untuk lebih meningkatkan pertanggungjawaban keuang instansi agar lebih efektif dan efisien kepada staf keuangan di pusat dan fakultas. Melalui kegiatan pelatihan ini para peserta tidak hanya diberikan materi-materi yang relevan dengan pemahaman system informasi akuntansi, tetapi juga mendapatkan bimbingan dan arahan dalam pembentukan karakter yang tangguh dalam meningkatkan pertanggungjawaban keuangan agar dihasilkan laporan keuangan yang dapat dipertanggungjawabkan .

Dengan demikian diharapkan para peserta setelah mengikuti kegiatan pelatihan ini akan memiliki ketrampilan dan pemahaman dalam sistem informasi akuntansi sebagai upaya meningkatkan pertanggungjawaban keuangan sesuai dengan instansi baik di fakultas atau universitas. Pemahaman Sistem Informasi Akuntansi bagi staf keuangan dapat digunakan untuk meningkatkan kinerja dalam pelaporan keuangan instansi. Konsep dasar pelatihan membangun kesadaran dalam pemahaman sistem informasi akuntansi instansi agar lebih 
bermanfaat dan berdaya guna yang baik.

Kegiatan ini telah berhasil dilaksanakan dengan baik dengan dihadiri oleh kurang lebih 26 peserta yang terdiri dari perwakilan staf keuangan di Unit-Unit Universitas, Fakultas dan Pusat .

\section{Analisis Teoritis}

Pelaksanaan pelatihan bagi masyarakat tidak dapat dicapai jika tidak dapat dukungan dari masyarakat. Ada kecederungan memandang materi penyuluhan hanya sebagai retorika belaka untuk itu diperlukan strategi penyelenggaraannya. Cara yang dipakai adalah dengan melakukan pendekatan kepada para peserta sebagai orang yang langsung berkaitan dengan permasalahan. Agar materi dapat dipahami dengan baik tentu harus dipilih metode penyampaian yang tepat, untuk itu akan digunakan metode pembelajaran simulasi dan tanya jawab. Metode ini akan merangsang peserta untuk tertarik dan berpartisipasi aktif dalam kegiatan pelatihan ini.

Pengetahuan akan tentang pemahaman system informasi akuntansi bagi instansi pemerintah wajib diketahui agar Pengelola keuangan tingkat universitas dan level fakultas dalam pengelolaan BLU akan memjalankan Aplikasi Keuangan SAKBLU ini yang mana Sistem Akuntansi Keuangan (SAK) adalah subsistem dari Sistem Akuntansi Instansi yang merupakan serangkaian prosedur yang saling berhubungan untuk mengolah dokumen sumber dalam rangka menghasilkan informasi untuk penyusunan neraca dan Laporan Keuangan serta laporan manajerial lainnya sesuai dengan ketentuan yangberlaku.

Sistem Akuntansi Pemerintah Pusat (SAAP) berlaku untuk seluruh unit organisasi Pemerintah Pusat dan unit akuntansi pada Pemerintah Daerah dalam rangka pelaksanaan Dekonsentrasi dan/atau Tugas Pembantuan serta pelaksanaan Anggaran Pembiayaan dan Perhitungan. Tujuan dari SAPP adalah:

1. Menjaga asset (safe guarding asset), agar asset pemerintah dapat terjaga melalui serangkaian proses pencatatan, pengolahan dan pelaporan keuangan yang konsisten sesuai dengan standar.

2. Memberikan informasi yang relevan, menyediakan informasi yang akurat dan tepat waktu tentang anggaran dan kegiatan keuangan pemerintah pusat.

3. Memberikan informasi yang dapat dipercaya tentang posisi keuangan suatu instansi dan pemerintah pusat secara keseluruhan.

4. Menyediakan informasi keuangan yang berguna untuk perencanaan, pengelolaan, dan pengendalian kegiatan dan keuangan pemerintah secara efisien.

\section{Khalayak dan Sasaran}

Khalayak dan sasaran dari kegiatan ini adalah perwakilan staf keuangan di fakultas unit-unit di 
Universitas dan keuangan pusat di Universitas Negeri Jakarta.

\section{Keterkaitan}

Kegiatan ini terkait dengan instansi seperti Universitas Negeri Jakarta yang membiayai kegiatan Pengabdian kepada Masyarakat yang dilaksanakan oleh dosen-dosen sebagai sebuah kewajiban atas Tridharma Perguruan Tinggi.

\section{KESIMPULAN DAN SARAN Kesimpulan}

Dalam era globalisasi serta tuntutan reformasi yang semakin meningkat, peran akuntansi sebagai alat pencatatan semakin dibutuhkan. Kepentingan itu tidak hanya diperuntukkan untuk pihak manajemen suatu entitas, tetapi juga untuk kebutuhan pertanggungjawaban (accountability) kepada banyak pihak yang memerlukan, Di dalam dunia bisnis (Commercial), akuntansi telah berkembang seiring dengan perkembangan bisnis tersebut. Hal ini menyebabkan akuntansi harus bisa menyesuaiakan dan berkembang seiring dengan perkembangan dunia bisnis.

Perkembangan akuntansi pemerintahan tidaklah secepat akuntansi bisnis. Penyebabnya adalah karakteristiknya tidak banyak mengalami perubahan. Dengan adanya tuntutan masyarakat menyebabkan akuntansi pemerintahan menjadi penting. Semakin besarnya dana yang dikelola oleh pemerintah semakin besar pula tuntutan akuntabilitas keuangan seba- gai wujud transparasi keuangan dalam pemerintahan sehingga diadakannya pelatihan pemahaman sistem informasi akuntansi dalam rangka untuk meningkatkan pertanggungjawaban keuangan instansi khususnya di Universitas Negeri Jakarta.

Hasil yang dicapai dalam kegiatan pelatihan ini ialah peserta merasa puas dan senang terhadap kegiatan tersebut. Terbukti dari data kehadiran, peserta tekun mengikuti kegiatan sampai selesai dengan jumlah tetap dan tidak berkurang. Peserta juga terlihat antusias dalam memberikan tanggapan dan pertanyaan kepada pembicara yang memandu kegiatan tersebut. Dapat disimpulkan bahwa kegiatan ini sangat diminati masyarakat, bahkan ada yang mengusulkan untuk dapat dilaksanakan kegiatan lanjutan.

\section{Saran}

Pemberian materi dalam pelatihan ini harus dipastikan tidak bersifat monoton dan bersifat massal dan seragam. Disarankan jika memang memungkinkan harus dilakukan kegiatan yang merupakan kelanjutan dari kegiatan ini sehingga hasil yang diharapkan lebih mengena kepada pokok permasalahan, karena pelatihan ini tidak akan memperoleh hasil yang memuaskan jika tidak ditindaklanjuti.

Selain itu kegiatan ini memang harus dikembangkan sebagai wujud pengabdian kepada masyarakat dalam rangka peningkatan kualitas pemahaman staf keuangan di lingkungan Universitas Negeri Jakarta. Untuk 
melaksanakan kegiatan yang efektif dengan hasil yang optimal dalam riil manfaatnya bagi peningkatan kesejahteraan masyarakat maka tidak terlepas dari dukungan dana yang memadai, agar kegiatan dapat dilakukan dalam jangka waktu yang lebih lama. Diharapkan ke depan jumlah dana yang dianggakan untuk kegiatan Pengabdian kepada Masyarakat bisa ditingkatkan jumlahnya.

\section{DAFTAR PUSTAKA}

Noordiawan, Dedi. 2009. Akuntansi Pemerintahan, Salemba Empat.

Modul, Sistem Akuntansi Keuangan, Kementerian Keuangan Republik Indonesia Program Percepatan Akuntabilitas Keuangan Pemerintah

Modul, Sistem Akuntansi Pemerintah Pusat, Kementerian Keuangan Republik Indonesia Program Percepatan Akuntabilitas Keuangan Pemerintah.
Peraturan Direktur Jenderal Perbendaharaan Nomor: Per$51 / \mathrm{Pb} / 2008$,Tentang Pedoman Penyusunan Laporan Keuangan Kementerian Negara/Lembaga

Peraturan Menteri Agama Nomor 17 Tahun 2006 Tentang Pembentukan Unit Akuntansi Keuangan Dan Unit Akuntansi Barang Milik Negara Di Lingkungan Kementerian Agama, Kementerian Agama Republik Indonesia, 2006

Peraturan Menteri Keuangan Nomor 171/PMK.05/2007, Kementerian Agama Republik Indonesia, 2008

Peraturan Pemerintah No.24 Tahun 2005 tentang Standar Akuntansi Pemerintah

Undang Undang No.1 Tahun 2004 tentang Perbendaharaan Negara

Undang Undang No.17 Tahun 2003 tentang Keuangan Negara 